\title{
IDENTIFYING MAJOR RISK ON ASPHALT MIXING PLANT BUSINESS IN BALI
}

\author{
Anak Agung Ayu Made Cahaya Wardani \\ Civil Engineering, Udayana University, Denpasar, Indonesia \\ I Nyoman Arya Thanaya \\ Coordinator of the Doctor of Engineering Study Program, Road Pavement Materials, \\ Udayana University, Denpasar, Indonesia \\ I Nyoman Yudha Astana \\ Civil Engineering, Udayana University, Denpasar, Indonesia \\ Anak Agung Gde Agung Yana \\ Civil Engineering, Udayana University, Denpasar, Indonesia \\ gungyana87@gmail.com
}

\begin{abstract}
The challenge of the construction world in Indonesia is the unpreparedness of this industry in facing competition at the local and global level. In dealing with industry 4.0 the costruction sector needs to improve the efficiency, reduce production cost and improve production process. Project succesfull can be seen from the effectiveness of the project in coordinating overall good factors, quality, cost and time of the project. The most importan thing to deal with is to identified the risk the risks faced in the main supply chain of the road project in Bali is one of the objectives of this research. This paper contribute to identify the risk experienced by the Asphalt Mixing Plant Unit as hotmix supplychain in Bali.

The questionnaire was distributed to 20 AMPs in Bali with the sampling technique used was purposive sampling. Risk analysis by determining Risk Exposure Value with Risk Consequence Index and Risk Probability index.

From the study was find out that the results of the validation test and the reliability test compared to $t$ arithmetic and $t$ table obtained that $t$ arithmetic is greater than $t$ table with a 95\% confidence level which means that all questions in the questionnaire declared valid. There are 77 risk was identified which 19 risk classified as unacceptabele risk, 23 risks classified as undesireable risk and 42 risks as desireable.
\end{abstract}

Keywords: Comparison, Cost, Time, VOC, Makassar City.

Cite this Article: Anak Agung Ayu Made Cahaya Wardani, I Nyoman Arya Thanaya, I Nyoman Yudha Astana, Anak Agung Gde Agung Yana, Identifying Major Risk on Asphalt Mixing Plant Business in Bali. International Journal of Civil Engineering and Technology, 11(1), 2020, 254-265.

http://iaeme.com/Home/issue/IJCIET?Volume=11\&Issue=1 
Anak Agung Ayu Made Cahaya Wardani, I Nyoman Arya Thanaya, I Nyoman Yudha Astana, Anak Agung Gde Agung Yana

\section{INTRODUCTION}

Infrastructure development is one of the priority agendas until 2024 with the 2019i allocation of infrastructure budget in 2020 increasing by 10 trillion to 430 trillion. The increase in the budget is generally caused by, among others, increased allocations to the Ministries / Institutions (K / L) in infrastructure including the maintenance and road and bridge construction, Special Allocation Funds (DAK) in Infrastructure, and government investment in infrastructure (Maulana, R., 2019).

The world of the Indonesian construction industry is a fourth generation industrial revolution or Industry 4.0 which is loaded with the use of technology so it must be responded with adequate data and human resources (HR) readiness. In dealing with industry 4.0, the construction sector also needs to improve where the construction industry business processes must be changed to improve efficiency, reduce production costs, bussiness networking, improve digitalisation and improve innovation. ((Desra, 2019). The Bina Marga design policy is to ensure the achievement of the level of road services throughout the life of the road service, is a minimum lifecycle cost, considers the ease of implementation and maintenance, uses efficient materials and utilizes local materials as much as possible, considers the safety factors of road users and considers environmental sustainability.(Law, 2017)

The challenge of the construction world in Indonesia in achieving success is the unpreparedness of this industry in facing competition at the local and global level. The construction industry in Indonesia still needs skilled and professional personnel as well as neat, efficient management in the improvement of the construction business and the development of genuine expertise by various parties. Other challenges are globalization, decentralization, use of information technology, lack of collaboration, organizational research, management and funding. (Desra, 2019). According to the old view, the success of a project can be seen from the effectiveness of the project in coordinating overall good factors, quality, cost and time of the project (Chan, 2002). Connecting all partners in the chain including the work unit of a company and external partners including suppliers, transport companies, and third-party companies including the risks faced in the supply chain is one of the objectives of supply chain risk management. Risks that occur include risks related to the quantity, quality, time of delivery of material supply, seasonal needs, weather, availability and adequacy of raw materials, environmental issues, quality, communication, finance and others (Hatmoko and Kistiani, 2017).

The problems that occur in the supply chain can of course have an impact on project performance, especially on road infrastructure projects in the Province of Bali, because road construction projects are a public need, so good supply chain management and management is needed from upstream to downstream. Project performance related to the supply chain is an increase in costs, a long completion time and decreased project quality (Bali Post, 17 May 2017).

From the above background, this research focuses on identifying major risks that occur in the road work supply chain in the Province of Bali, namely identifying major risks in the production process and operational of hot mix asphalt production units (AMP) using the Value at Risk (VAR) method. By knowing the major risks in the AMP unit, it is expected that the risk can then be mitigated and mapping the risks in the AMP unit supply chain so that the AMP unit can become a resilient supply chain that can ultimately improve the performance of road construction projects in Bali Province. 


\section{DEFINITION OF RISK}

According to the Big Indonesian dictionary risk is an unpleasant result of an action or action. According to the human-social view, it is stated that risk is an unwanted realization force where the consequences are opposite for human survival, health, property and the environment. Risk is a function of the level of uncertainty due to the influence of an event. The definition of risk according to the Australian / New Zealand Risk Management Standard (AS / NZ Standard), states that risk is the possibility of things that can have a negative or positive impact on certain objectives to be achieved.

Risk is defined as the distribution of variations that are likely to arise, their similarity and subjective value fundamentally. All choices in life involve risk and risk comes from uncertainty. All uncertainties are caused by lack of information, knowledge and experience (Ghahramanzadeh, 2013).

So the risk can be broadly defined as the chance of an unwanted event resulting from the uncertainty of an event that can have a negative and positive impact, but can be reduced through information, knowledge and experience in dealing with it

\subsection{Types of Risk}

Types of risks can be grouped into several characteristics and risk categories. To facilitate the understanding of risk, the risk is carried out by measurement, interpretation of different meanings depending on the research conducted. Risk based on sources can be seen in Figure 2.1 (Jüttner 2010). Researchers categorize risks depending on the typology.

The categories are:

a. Risks originating from the environment caused by uncertainty of the supply chain and its interaction with the environment Examples of socio-political consequences, fire, weather, earthquake, etc.

b. Risks originating from within the organization such as workers or production uncertainty

c. Risk associated with networking with other parties in the supply

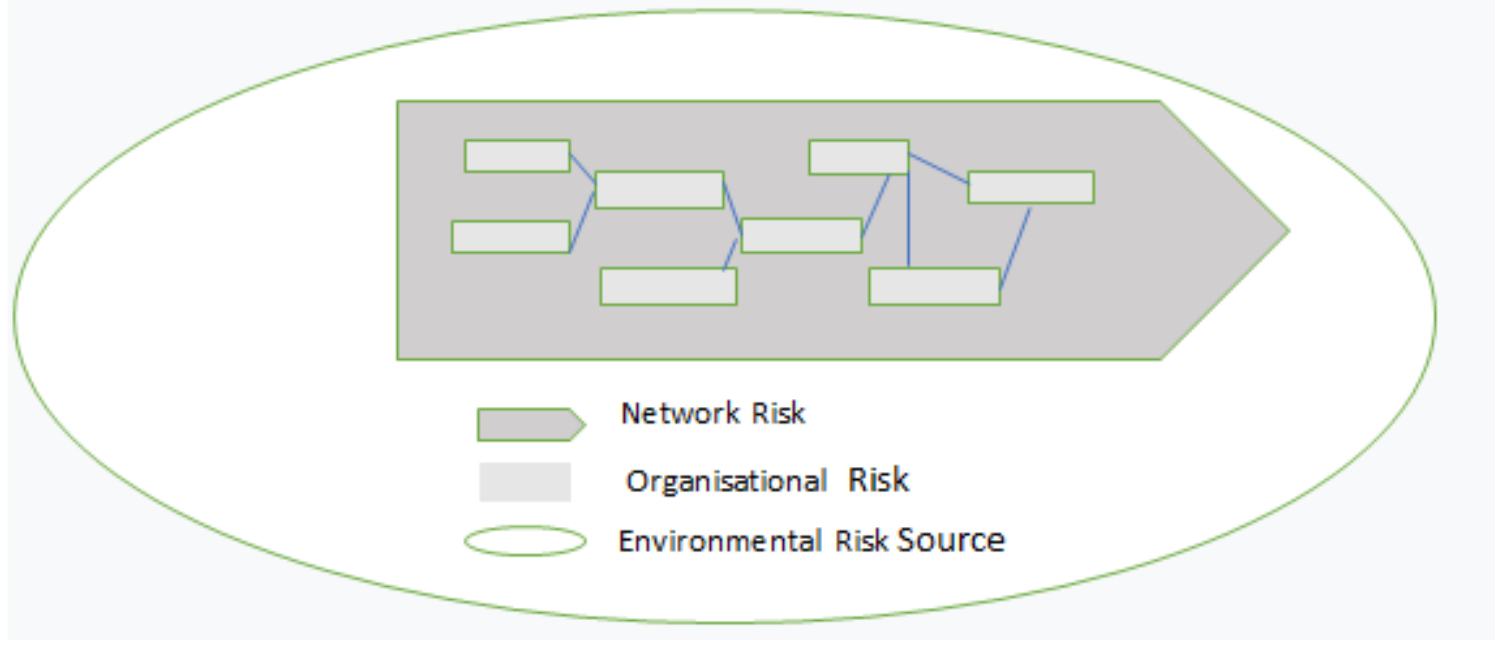

Figure 2.1 Risk Source

Source : (Jüttner, 2010)

From Figure 2.1 it can be seen that environmental and internal organizational factors are a source of risk to the entire supply network while the relationships between networks affect the risk of the entire network. In some industries RM is still understood as a specific part of a company, JuTner, et al (2003) states that few understand that the risk concerns all supply 
chains. Chopra and Sodhi (2004) classify supply chain risks in nine categories, namely: Disturbances, delays, systems, forecasting, intellectual property, procurement, revenue, inventory and capacity. Wagner (2008) divides supply chain risk into two classes and five categories, namely: 1. Internal: a. Demand side, b. Supply side, 2. External: a. Regulations, permits and bureaucracy, b. Infrastructure and c. Catastrophic. Goh, et al (2007) states that there are two types of supply chain risk in terms of sources, namely risks arising from supply chain internal networks and risks arising from external factors. Whereas Tang (2006) classifies supply chain risks based on operational risks and risks due to disruptions. Operational risk is associated with uncertainty in the supply chain including demand, supply and uncertainty of costs. Likewise Christopher and Peck (2004) categorized risk into three categories and then divided into five sub-categories, namely: 1. Internal for the company a. Process b. Control 2. External for the company but internal for the supply chain network a. Request b. Supply 3. External to the supply chain network a. Environment

\subsection{SUPPLY CHAIN}

Supply chain (supply chain) is a system where organizations distribute production goods and services to their customers and work together in increasing value for their customers (Lee, 2002). This chain is also a network or network of various interconnected organizations that have the same goal, which is as good as possible to carry out the procurement or distribution of the goods. Supply chain is also said to be a logistics network.

Supply chain is a network organization of suppliers, production machines, warehouses and distributed from raw materials to finished materials and then distributed to consumers. Supply chain planning includes network configuration, number, location, capacity and technology and then planning material purchasing, processing and distribution needs. (Santoso, et al, 2014). The most important component in planning manufacturing activities is designing and operating the supply chain efficiently.

Meanwhile, Ling Li (2007) explained that the supply chain places more emphasis on all activities in meeting the needs of consumers in which there is a flow and transformation of goods from raw materials to end consumers and is accompanied by a flow of information and money. In this connection, there are several parties who are companies that have the same interests, namely:

\section{Suppliers}

\section{Manufacturing}

\section{Distribution}

\section{Retail outlets}

\section{Customer}

So the supply chain is related to the process of managing more detailed and earlier products such as supplier selection, raw materials, manufacturing of finished products, product design, warehouse management, inventory management, product innovation, and others. In Figure 2.4, the relationship between supply chains is directly related to the complete cycle of raw materials from suppliers to production, to the warehouse and then to the end user. As for the actors in the industry include suppliers of raw materials, or suppliers of components and parts, or suppliers of semi-finished goods (sub-assembly suppliers), producers of products and services, distributors and end with end consumers (end consumers). Each of these actors is linked to a chain of cooperation in supporting industrial activities, so as to produce a product or service that can be enjoyed by end consumers. The activity chain is called the supply chain (Tjipto S, 2014). 


\subsection{Risks to the Amp Supply Chain}

Risk identification according to Tummala (2011) is the first step in the risk management process. Risk identification involves comprehensive and structured risk. Risk areas must be identified clearly and carefully so that risk mitigation strategies can be implemented because they can affect other risk areas.

Risk identification starts from identifying the network in the AMP unit, which starts from the aggregate supplier of raw materials and then the goods are stored in the warehouse before being used. Furthermore, if there is a delivery schedule, raw materials will be produced at the processing plant. Goods will be sent to consumers to be ready to be spread. Before the concrete asphalt is sent a specimen is sent. Figure 2.9 shows a concrete asphalt production flowchart on the AMP basecamp. Broadly speaking the stages of activities in the AMP supply chain network can be sorted in SIPOC (Supply, Input, Process, Output, Customer) SIPOC summary can be seen in Table 2.1

Table 2.1 Production Stage Identification on AMP unit

\begin{tabular}{|c|l|}
\hline Phase on Production Process & \multicolumn{1}{|c|}{ Explanation } \\
\hline Supply & Prepatation of Raw material \\
\hline Input & $\begin{array}{l}\text { Supporting processes in the implementation of } \\
\text { overall business processes }\end{array}$ \\
\hline Process & $\begin{array}{l}\text { Production, material testing and production results } \\
\text { Production, material testing and production results }\end{array}$ \\
\hline Output & Spring products and hotmix products, transportation \\
\hline Customer & $\begin{array}{l}\text { Receipt of orders, receipt of production and } \\
\text { payment }\end{array}$ \\
\hline Source : Analysed, 2018 & \\
\hline
\end{tabular}

According to (Ghahramanzadeh, 2013 )the risk management cycle consists of risk identification, risk assessment, risk mitigation and risk monitoring and control and is described in the framework of the risk management cycle in the following figure 2.1:

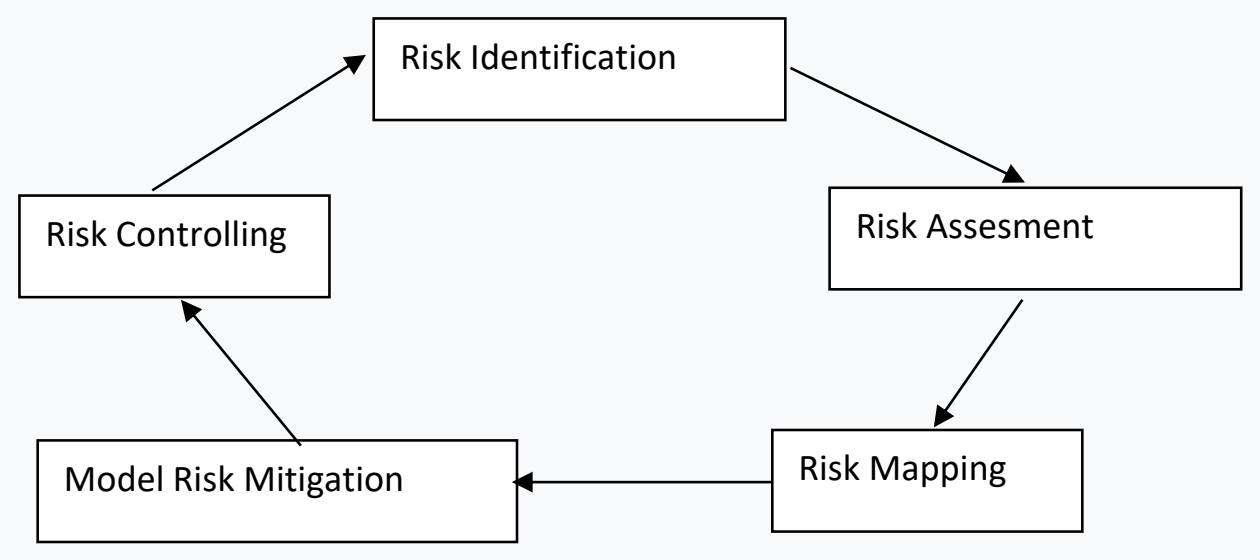

Figure 2.2 Risk Stage

Source : (Ghahramanzadeh, 2013 ) 
Anak Agung Ayu Made Cahaya Wardani, I Nyoman Arya Thanaya, I Nyoman Yudha Astana, Anak Agung Gde Agung Yana

\subsection{Identification of Activities that Generate Risk in the Amp Unit}

There are many ways to approach creating a risk category. Some approaches used are the Anderson \& Schroede method which emphasizes the physical disaster approach and originates from outside the organization such as natural disasters, economics, financial commodities, etc. and the Duckert (2011) approach is a method that uses a business process approach. From here it will be used to design a risk category model. The main business process is a process carried out by the organization everyday to meet the needs of customers and other interested parties. Which can result in risk for AMP units. Besides that, there are business processes that need support in the main business processes, for example engineering, information systems, marketing and sales, supply chain management and maintenance and utilities. The advantage of this approach is that it is easier to map business functions, processes, and easier to obtain consensus on the types and categories of risk. Namely the main business processes, supporting business processes and supporting business processes.

After the business activity process in the AMP unit is identified the next step is to identify activities that can generate risk. In the process of producing business activities activities that use the SIPOC approach, Fajar (2011), namely Supplier-Input-Process-Output-Customer, enters into Six Sigma theory, a method for obtaining maximum results by minimizing defects or errors. SIPOC consists of a raw material supply system, activities for receiving raw materials to the production process, output to receiving goods by the customer. According to Pavlou and Manthou (2008) business processes can be divided into 3 parts, namely the top grouped in meeting the needs of consumers aligned with the company's production capacity and capability, the middle part is a production support process in the form of equipment, maintenance, production support activities such as employee training, maintenance machinery, warehousing, etc. as well as the lower part are the administrative and management offices of supporting operational offices. In summary, this process mapping can be seen in Table 2.2

Table 2.2. Business Process in Asphalt Mixing Plant

\begin{tabular}{|l|l|l|}
\hline \multicolumn{1}{|c|}{ Upper } & \multicolumn{1}{c|}{ Middle } & \multicolumn{1}{c|}{ Lower } \\
\hline Customers demand fulfillment & Production support process & Document controlling \\
\hline Receipt of order & Purchasing & Quality note \\
\hline Capacity Check & Machine Maintenance & Corrective action \\
\hline Check availability of stock & Employee training & Audit \\
\hline $\begin{array}{l}\text { Check availability of production } \\
\text { machinery and equipment }\end{array}$ & Proses kalibrasi mesin & Cusomer complainging \\
\hline Production Process & Warehousing process & \\
\hline
\end{tabular}

Source : Pavlou dan Manthou (2008)

According to Christopher, M., et al (2004) sources of risk in the supply chain consist of risks originating from supply, demand, process, control, and environmental activities. A complete picture of the identification of business processes can be explained in Figure 2.4 as follows:

- Business processes are focused on meeting the demands of consumers, the production process, and the distribution and transportation of products to consumers.

- Then the middle part is the supporting process of the production process. Among them are the purchasing process, the machine maintenance process, the employee training process, the calibration process, and the warehousing process.

- The lower part is a process that supports the quality that is in the company. These processes are: document control, quality records, corrective actions, auditing, and handling customer complaints. 
Furthermore, from this business identification interviews, field studies, observations, literature studies and FGDs to determine the risks inherent in AMP's business activities are in Bali. Interviews were conducted on 20 AMPs found in Bali, by visiting the AMP and conducting interviews and observations of events that occurred. This risk occurs during the stages of AMP business implementation. To provide an assessment of the probabilities and impacts of identified risks.

\section{RISK ANALYSIS METHOD}

Risk is a combination of the probability of an event and the consequences of that event, by not excluding the possibility that there are more than one consequence for the event and the consequences can be positive and negative (Sentosa in Advance 2015). The stages of risk analysis using the Value at Risk Method are:

Risk Ranking

Risk ranking is based on determining the Exposure Value of each supply chain risk. Risk ranking is formulated as:

Risk Exposure Value at Risk Factor $=$ Risk Consequence Index x Risk Probability index (2.1) The Risk Consequence Index can be seen in Table 2.3

Table 2.3 Risk Consequence Index

\begin{tabular}{|l|c|c|}
\hline $\begin{array}{c}\text { Consequence Severity } \\
\text { Level }\end{array}$ & Risk Consequence Index & Code \\
\hline Very large & 5 & A \\
\hline Large & 4 & B \\
\hline Medium & 3 & C \\
\hline Small & 2 & D \\
\hline Very small & 1 & E \\
\hline
\end{tabular}

Source : (Tummala, 2011)

The probability value of a risk event can be seen in Table 2.4 The value of the Risk exposure can be seen in Table 2.5

Table 2.4 Index and Probability Category

\begin{tabular}{|l|l|c|}
\hline \multicolumn{1}{|c|}{$\begin{array}{c}\text { Category of Risk } \\
\text { Probability }\end{array}$} & \multicolumn{1}{|c|}{ Risk Frequent } & Index of number \\
\hline Very often & Once a week & 5 \\
\hline Often & Once a month & 4 \\
\hline Sometimes & Once per year & 3 \\
\hline Rarely & More than one per decade & 2 \\
\hline Very rarely & One in decade & 1 \\
\hline
\end{tabular}

Source : (Tummala, 2011)

Table 2.5 The value of the Risk exposure

\begin{tabular}{|l|c|c|c|c|c|}
\hline \multicolumn{1}{|c|}{ Severity } & $\begin{array}{c}\text { Frequent } \\
\text { Index=5 }\end{array}$ & Often Indeks = 4 & $\begin{array}{c}\text { Infrequent } \\
\text { Index = 3 }\end{array}$ & Rare Index = 2 & $\begin{array}{c}\text { Extremely rare } \\
\text { Index = 1 }\end{array}$ \\
\hline $\begin{array}{l}\text { Catastrophic (index } \\
=5 \text { ) }\end{array}$ & 25 & 20 & 15 & 10 & 5 \\
\hline Critical (index =4) & 20 & 16 & 12 & 8 & 4 \\
\hline Serious index(3) & 15 & 12 & 9 & 6 & 3 \\
\hline Marginal (index = & 10 & 8 & 6 & 4 & 2 \\
\hline $\begin{array}{l}\text { Negligible Index = } \\
\text { 1) }\end{array}$ & 5 & 4 & 3 & 2 & 1 \\
\hline
\end{tabular}

Source: (Tummala, 2011) 
The level of risk acceptance with a value between 11 and 16 is referred to as the catastrophic class. Risks between 10 and 6 can be categorized as critical classes. While risks between 1 and 5 are classified neligible.

After risks are classified, the level of risk acceptance can be determined. Team organizations, senior management must be involved in determining these criteria. The level of risk acceptance can be seen in Table 2.6 below.

Table 2.6 can be explained as follows:

1. Unacceptable: risk is not acceptable, must be eliminated or transferred

2. Undesireable: risks are not expected and must be eliminated

3. Acceptable: risk is acceptable

4. Negligible: risk can be ignored

Table 2.6 The Level of Risk Acceptance

\begin{tabular}{|l|c|c|c|c|c|}
\hline \multicolumn{1}{|c|}{$\begin{array}{c}\text { Concequence } \\
\text { Likehood }\end{array}$} & Catastropic & Critical & Serious & Marginal & Neligible \\
\hline \multirow{2}{*}{ Frequent (5) } & Unacceptable & Unacceptable & Unacceptable & Unacceptable & Undesireable \\
& 25 & 20 & 15 & 10 & 5 \\
\hline \multirow{2}{*}{ Often (4) } & Unacceptable & Unacceptable & Unacceptable & Undesireable & Udesireable \\
& 20 & 16 & 12 & 8 & 4 \\
\hline \multirow{2}{*}{ Infrequentl (3) } & Unacceptable & Unacceptable & Undesireable & Undesireable & Acceptable \\
& 15 & 12 & 9 & 6 & 3 \\
\hline \multirow{2}{*}{ Rare (2) } & Undesireable & Undesireable & Undesireable & Acceptable & Acceptable \\
& 10 & 8 & 6 & 4 & 2 \\
\hline \multirow{2}{*}{ Extremely rare (1) } & Acceptable & Acceptable & Acceptable & Neligible & Neligible \\
& 5 & 4 & 3 & 2 & 1 \\
\hline
\end{tabular}

Source : (Tummala, 2011)

\subsection{Samples}

In this study the sampling technique used was purposive sampling. Purposive sampling is a sampling technique with certain considerations or special considerations in choosing respondents who are believed to be able to provide answers to the questionnaire in accordance with the research topic.

According to Eriyanto the purposive sample is another development of an arbitrary sample (convenience sampling). In any random sample there is no consideration in the selection of respondents while in the purposive technique the sample is determined based on certain considerations in order to obtain a sample that has an argument that can be scientifically justified.

Based on these criteria and the purpose of this study is to determine the major risks that occur in the hot asphalt supply chain production process and determine the mitigation undertaken in dealing with these risks. Respondents are production managers at the AMP and other parties such as AMP owners, consultants, Public Works Offices and academics. Criteria for respondents chosen later are:

1. Knowing the risks that occur in asphalt supply chain companies

2. Has worked in a company for at least 3 years

3. Have a minimum high school education background.

4. Respondents have the competence and experience in risk mitigation in the asphalt supply chain 


\subsection{Data Collection Techniques}

In this study, there are methods / data collection techniques used are divided into 2 stages. The first step is to find out the risk and measure the risk using a questionnaire or questionnaire technique combined with the interview method. The instrument used was a list of questions given to respondents who would later respond according to requests on the questionnaire. The questionnaire will be distributed to respondents who will be used as samples in this study. The second stage is the collection of data on ISM mitigation and assessment through a Focus Group Discussion that will be held after the first stage is completed, the selection of FGD members is carried out by people who have expertise and competence in their fields consisting of: Contractors, Consultants, Project Owners, academics and competent persons in AMP management

In this study questionnaire measurements using a Likert scale. The research questionnaire consisted of 2 (two) types

1. Questionnaire to measure impact and probability using the Likert 1-5 scale as follows:

1. Very high (very high) $=5$

2. High $($ high $)=4$

3. Medium $($ medium $)=3$

4. Small (low) $=2$

5. Very small $=1$

\section{ANALYSIS OF MAJOR RISKS IN AMP UNIT BUSINESS} ACTIVITIES IN BALI PROVINCE

Graph of Quantity and Percentage of each of the Risk Revenues

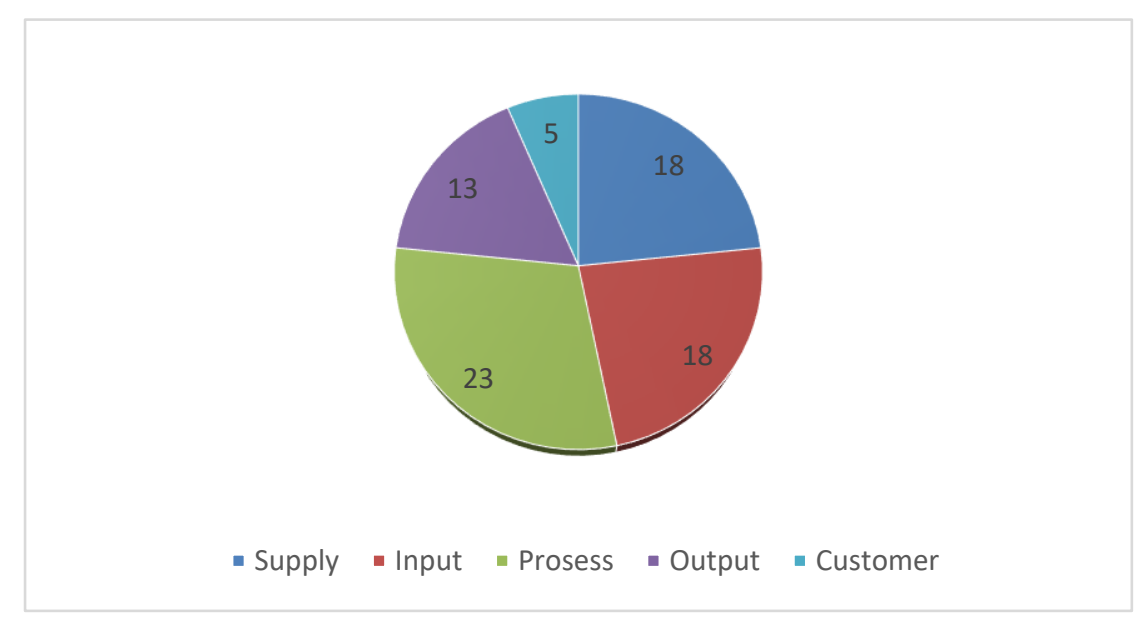

Figure 4.1 Quantity and Percentage of Risk

Source : Analised, 2019 
Anak Agung Ayu Made Cahaya Wardani, I Nyoman Arya Thanaya, I Nyoman Yudha Astana, Anak Agung Gde Agung Yana

\subsection{Frequency and Impact on Major Unacceptable Risks}

In the AMP Business Activity Process, 77 risks were identified with the details in Table 4.1

Table 4.1 Identified Risk Table for AMP Business Activities

\begin{tabular}{|c|c|c|c|c|}
\hline No & Nama Kegiatan & $\begin{array}{c}\text { Jumlah Risiko } \\
\text { teridentifikasi }\end{array}$ & $\begin{array}{c}\text { Nilai } \\
\text { Cronbach's } \\
\text { Alpha } \\
\text { Probabilitas }\end{array}$ & $\begin{array}{c}\text { Nilai } \\
\text { Cronbach's } \\
\text { Alpha Dampak }\end{array}$ \\
\hline 1 & Supply & 18 & 0,893 & 0,908 \\
\hline 2 & Input & 18 & 0,898 & 0,901 \\
\hline 3 & Process & 23 & 0,951 & 0,946 \\
\hline 4 & Output & 13 & 0,85 & 0,857 \\
\hline 5 & Demand & 5 & 0,944 & 0,940 \\
\hline
\end{tabular}

Source : Analised, 2019

The questionnaire was distributed to 20 AMPs found in Bali. Then the questionnaire was recapitulated the validation and reliability tests were conducted. From the results of the validation test and the reliability test compared to $\mathrm{t}$ arithmetic and table obtained that $\mathrm{t}$ arithmetic is greater than $t$ table with a $95 \%$ confidence level which means that all questions in the questionnaire declared valid. Statistic analysis was conducted to find the modus of the probability and impact of the questionnaire,. Major Unacceptable Risks is find from equation 1 can be seen in Table 4.2

Table 4.2 Unacceptable Risk VAR

\begin{tabular}{|c|c|c|c|c|c|}
\hline No & Kode & Risiko & $\begin{array}{c}\text { Modus of } \\
\text { Probability }\end{array}$ & $\begin{array}{c}\text { Modus of } \\
\text { Impact }\end{array}$ & VAR \\
\hline 1 & RS6 & Material quality & 3 & 3 & 9 \\
\hline 2 & RS11 & Competitor exintence & 4 & 4 & 16 \\
\hline 3 & RI1 & $\begin{array}{l}\text { Economic issue ; external and } \\
\text { internal }\end{array}$ & 3 & 4 & 12 \\
\hline 4 & RI2 & Project bid price & 3 & 3 & 9 \\
\hline 5 & RI5 & Managerial and operational & 3 & 5 & 15 \\
\hline 6 & RI6 & $\begin{array}{l}\text { Lack of human resources } \\
\text { training }\end{array}$ & 3 & 4 & 12 \\
\hline 7 & RI8 & Weather & 3 & 4 & 12 \\
\hline 8 & RI9 & Environment and society & 3 & 4 & 12 \\
\hline 9 & RI10 & Bad condition of Warehaouse & 3 & 4 & 12 \\
\hline 10 & RI15 & Material price & 3 & 4 & 12 \\
\hline 11 & RI16 & Asphalt price & 3 & 4 & 12 \\
\hline 12 & RP9 & Land project preparation & 3 & 4 & 12 \\
\hline 13 & RP12 & $\begin{array}{l}\text { Damage to generator, electricity } \\
\text { and other equipment }\end{array}$ & 4 & 4 & 16 \\
\hline 14 & RP21 & Lack of treatment time & 3 & 4 & 12 \\
\hline 15 & $\mathrm{RO} 2$ & Lack of transport fleet & 3 & 4 & 12 \\
\hline 16 & RO4 & Long overtime hours & 3 & 4 & 12 \\
\hline 17 & RO5 & Quality test & 3 & 4 & 12 \\
\hline 18 & RO9 & Polution & 3 & 3 & 9 \\
\hline 19 & RC5 & $\begin{array}{l}\text { Complaint and customer } \\
\text { reputation }\end{array}$ & 3 & 4 & 12 \\
\hline
\end{tabular}

Source : Data Analised, 2019 
Identifying Major Risk on Asphalt Mixing Plant Business in Bali

Table 4.3 Risiko Mayor Katagori Undesireable

\begin{tabular}{|c|c|c|c|c|c|}
\hline No & Kode & Risiko & $\begin{array}{c}\text { Modus of } \\
\text { Probability }\end{array}$ & $\begin{array}{l}\text { Modus of } \\
\text { Impact }\end{array}$ & VAR \\
\hline 1. & RS3 & $\begin{array}{l}\text { Demand that exceed production } \\
\text { capacity }\end{array}$ & 3 & 3 & 9 \\
\hline 2 . & RS15 & Delivery delay due to disaster & 3 & 3 & 9 \\
\hline 3. & RI4 & $\begin{array}{l}\text { Lack of experience human } \\
\text { resources }\end{array}$ & 2 & 3 & 6 \\
\hline 4. & RI11 & Lack of warehouse & 3 & 3 & 9 \\
\hline 5. & RI12 & $\begin{array}{l}\text { Adverse material due to } \\
\text { originating from one source }\end{array}$ & 3 & 4 & 12 \\
\hline 6. & RI13 & Material quality & 2 & 4 & 8 \\
\hline 7. & RI14 & $\begin{array}{l}\text { Adequacy of material } \\
\text { availability }\end{array}$ & 2 & 4 & 8 \\
\hline 8. & RI17 & $\begin{array}{l}\text { Material, equipment and human } \\
\text { resource unprepare }\end{array}$ & 2 & 3 & 6 \\
\hline 9. & RP1 & Unprepared of the project & 3 & 3 & 9 \\
\hline 10. & RP2 & Production capacity & 2 & 4 & 8 \\
\hline 11. & RP4 & Material availability & 2 & 4 & 8 \\
\hline 12. & RP5 & Filter device damage & 2 & 4 & 8 \\
\hline 13. & RP8 & Lack of machinery sparepart & 2 & 4 & 8 \\
\hline 14. & RP10 & Filter blocked & 3 & 3 & 9 \\
\hline 15. & RP22 & $\begin{array}{l}\text { Coordination between unit } \\
\text { section }\end{array}$ & 3 & 3 & 9 \\
\hline 16. & RO1 & Transport delay & 2 & 4 & 8 \\
\hline 17. & $\mathrm{RO} 3$ & Project breaktime & 3 & 3 & 9 \\
\hline 18. & RO7 & Damage to the transport fleet & 3 & 3 & 9 \\
\hline 19. & RO8 & Long distance sending & 3 & 3 & 9 \\
\hline 20. & RO11 & Change in hue of shrine & 3 & 3 & 9 \\
\hline 21. & RO13 & Change in sanctuary population & 3 & 3 & 9 \\
\hline 22. & $\mathrm{RC} 2$ & Change in environmental setting & 3 & 3 & 9 \\
\hline 23. & $\mathrm{RC} 3$ & Late payment & 3 & 3 & 9 \\
\hline
\end{tabular}

Source : Data Analised, 2019

The distribution of the level of risk acceptance in each group of production process flow based on the assessment and risk acceptance can be seen in the following Table 4.4

Table 4.4 Major Risk Recording

\begin{tabular}{|c|c|c|c|c|c|c|c|c|c|c|c|}
\hline \multirow[t]{2}{*}{ No } & \multirow[t]{2}{*}{ Proses } & \multirow[t]{2}{*}{ Jumlah } & & \multicolumn{8}{|c|}{ Penerimaan Risiko } \\
\hline & & & Persentase & Unacceptable & Persentase & Undesireable & Persentase & Acceptable & Persentase & Neligible & Persentase \\
\hline 1 & Supply & 18 & 23,37 & 2 & 11,11 & 3 & 16,77 & 13 & 72,22 & 0 & 0 \\
\hline 2 & Input & 18 & 23,37 & 9 & 50 & 6 & 33,33 & 3 & 16,67 & 0 & 0 \\
\hline 3 & Process & 23 & 29.87 & 3 & 13,04 & 7 & 30,435 & 13 & 56,525 & 0 & 0 \\
\hline 4 & Output & 13 & 16.88 & 4 & 30,77 & 6 & 46,15 & 3 & 23,01 & 0 & 0 \\
\hline 5 & Customer & 5 & 6.4 & 1 & 20 & 2 & 40 & 2 & 40 & 0 & 0 \\
\hline \multicolumn{2}{|r|}{ Total } & 77 & 100 & 19 & & 23 & & 28 & $\mathrm{o}$ & 0 & \\
\hline \multicolumn{2}{|c|}{ Persentase } & & & 4 & & 62 & & 34 & & & \\
\hline
\end{tabular}

Source : Data Analised, 2019 
Anak Agung Ayu Made Cahaya Wardani, I Nyoman Arya Thanaya, I Nyoman Yudha Astana, Anak Agung Gde Agung Yana

\section{CONCLUSION AND SUGGESTION}

From the result of the study, there are 77 risk identify, that almost 34 percent of the risk are an acceptable risk, 23 percent as undesireable and risk catagorised as unacceptable. Most of the risk source from Input stage almost 50 percent and 46 percent form output stage, which the stage need to be be improve, in order to resilient with the risk. The purposed of the risk management is a tool to manage the risk and found out its strategic mitigation.

The identify risk can be adopted by SC managers, government and other stakeholder to improve supply chain performance and get the most appropriate decision making in Asphalt Mixing Plant business.

\section{REFERENCES}

[1] Maulana, R, Bisnis.com., Hadapi Industri 4.0, PUPR Siapkan Inovasi di Sektor Konstruksi,, 2018 diakses tgl 17 Agustus 2019

[2] Desra, Company Strategy in Facing the Industrial Revolution Era 4.0, https://www.jurnal.id/id/blog, 2019, Accesed, 1 January 2020

[3] Hatmoko, J., U,D, dan Kistiani, F. 2017. "Model Simulasi Risiko Rantai Pasok Material Proyek Konstruksi Gedung." Media Komunikasi Teknik SIpil.

[4] Chan, A.P.C. et al. (2002). Framework of success criteria for design/build projects, Journal Managerial Engineering, Vol. 18, No. 3, pp. 120 - 128.

[5] UU no 2 tahun 2017, Act on construction services, 2017

[6] Liu, H.C., Liu, L., dan Bian, Q. "Failure Mode and Effects Analysis Using Fuzzy Evidential Reasoning Approach and Grey Theory." Expert Systems with Applications, 2017

[7] Santoso, T., Ahmed, S., Goetschalckx, M., dan Shapiro, A. 2014. "A Stochastic Programming Approach for Supply Chain

[8] Lee, Aligning supply chain strategy with produc uncertainty , California Management Review, 2002

[9] Ju€Ttner, U., Peck, H., dan Christopher, M. 2003. "Supply Chain Risk Management: Outlining an Agenda for Future Research." International Journal of Logistics: Research and Applications 6 (4):199-210.

[10] Tjipto S, I. 2014. "Analisis KInerja Pemasok Pada Manajemen Rantai Pasokan Perusahaan Jasa Konstruksi." Jurnal Manajemen.

[11] Tjipto S, I. 2014. "Analisis KInerja Pemasok Pada Manajemen Rantai Pasokan Perusahaan Jasa Konstruksi." Jurnal Manajemen.

[12] Fajar, T. 2011. "Materi Psikologi Industri \& Organisasi, Politeknik Manufaktur (POLMAN) Astra." https://istilah-humanresource.blogspot.com/2011/11/apa-itu-s-i-p-oc.html

[13] AS/NZS ISO 31000:2009

[14] Ghahramanzadeh, M. 2013. "Managing Risk of Construction Projects A case study of Iran." Doctoral dissertation, University of East London.

[15] Tummala, R. 2011. "Assessing and managing risks using the Supply Chain Risk Management Process (SCRMP)." Supply Chain Management: An International Journal

[16] Anderson, John C, Gary Cleveland and Roger G. Schroeder, "Operations Strategy: A Literature Review," Working Paper, Operation Management Center, Carlson School of Management, University of Minnesota, April 1986. 